\title{
The Impact of Using Echinacea as a Complementary Modality on ICU Length of Stay and Mortality in Intubated and Ventillated Patient
}

\author{
JEHAN A. EL-KHOLY, M.D.*; IMAN A. FOUAD, M.D.*; AKRAM S. EL-ADAWY, M.D.*; \\ HEBA F. SHAFEI, M.D.** and MONA S. ALLAM, M.Sc.*
}

The Department of Anesthesiology, Intensive Care and Pain Management, Faculty of Medicine, Cairo University* and The Department of Complementary and Alternative Medicine, National Research Center, Giza**, Egypt

\begin{abstract}
Background: Ventilator Associated Pneumonia (VAP) is a common concern in Intensive Care Unit (ICU), where many risk factors have been reported to be associated with it. VAP can increase patient's length of stay in ICU and possibly causes high mortality rate. Application of several interventions have been found to reduce incidence of VAP, including head of bed elevation, deep vein thrombosis prophylaxis, peptic ulcer disease prophylaxis, daily sedation vacation, daily assessment for readiness for extubation, daily spontaneous breathing trial, and oral care with chlorohexadine. These interventions are called ventilator care bundle. Echinacea is a herb that has been utilized to strengthen the body's innate resistance. It contains multiple active compounds which gives it its medicinal qualities, it has been shown to reduce the severity of respiratory infections.
\end{abstract}

Aim of Study: The aim of this study was to evaluate the effect of adding Echinacea to ventilator care bundle in intubated and ventilated ICU patient on length of stay in ICU and mortality.

Material and Methods: This clinical trial included 80 patients who were intubated and mechanically ventilated within 48 hours of admission to ICU in Surgical Intensive Care Unit (SICU) in Kasr Aini Hospital during the period between December 2013 and December 2014. All patients were adults more than 18 years, who have no witnessed aspiration or pneumonia on admission.

Intervention: Patients were divided into two equal groups of 40 patients each, one group received Echinacea in the form of Immulant capsules and the other didn't receive it. Both groups have ventilator care bundle applied. All patients were followed-up clinically, radiologically and by laboratory. Length of ICU stay, mortality and VAP associated mortality were calculated in both groups.

Results: Both length of stay in ICU and mortality had no statistical significance in both groups, but VAP associated

Correspondence to: Dr. Jehan A. El-Kholy, The Department of Anesthesiology, Intensive Care and Pain Management, Faculty of Medicine, Cairo University mortality had decreased significantly in the group that received Echinacea.

Conclusion: Echinacea may be found to decrease VAP associated mortality.

Key Words: Echinacea-Ventilator care bundle - Ventilator associated pneumonia - Intensive care unit Length of stay in ICU - Mortality.

\section{Introduction}

VENTILLATED patients are prone to many complications one of which is Ventilator Associated Pneumonia (VAP). VAP is one of the most commonly encountered hospital acquired infections seen in the critical care setting and can be linked to several adverse clinical outcomes. It is defined by the United States Center for Disease Control and prevention as pneumonia occurring 48 hours or longer after the initiation of mechanical ventilation [1]. VAP is a complication in as many as $28 \%$ of patients who receive mechanical ventilation. And so any patient who is mechanically ventilated is at risk for VAP that can be complicated by increased ICU length of stay and mortality. The rate of contracting VAP has been described as 3\% per day during the first week of mechanical ventilation, $2 \%$ per day in the ensuing weeks. The overall incidence of VAP ranges widely from 5\% to 67\% depending on the diagnostic criteria used [2]. The crude mortality rate for VAP is $27-76 \%$. Pseudomonas or Acinetobacter pheumonia is associated with higher mortality rates than those associated with other organisms. Studies have consistently shown that a delay in starting appropriate and adequately dosed antibiotic therapy increases the mortality risk [3]. Outcomes are also related to the timing of the onset of VAP. Early onset pneumonia occurs within the first 4 days of hospitalization, 
whereas late onset VAP develops 5 or more days after admission. Late onset pneumonias are usually associated with multidrug resistant organisms [4]

Many guidelines have been developed to try to deal with this serious condition. One recent approach involves the use of care bundle. A care bundle identifies a set of key interventions from evidence-based guidelines that, when implemented, are expected to improve the patient outcome [5] The aim of care bundles is to change patient care processes and thereby encourage guideline compliance.

The institute of Healthcare Improvement developed a ventilator bundle that consists of evidencebased interventions to decrease the incidence of VAP. The interventions include head of bed elevation 30 degrees or higher, deep venous thrombosis and peptic ulcer prophylaxis, oral care with chlorohexadine, sedation vacation and waning assessment [6]

Echinacea has been utilized for its medicinal properties for over 400 years by Native Americans to treat infections and general illnesses. This herb contains multiple active compounds, which includes volatile oils, alkamides, glycoproteins, flavonoids and polysaccharides. The combinations of these chemicals give Echinacea its medicinal qualities. Echinacea strengthens the body's innate resistance and, if indeed the hyaluronidase enzyme inhibiting action is a factor, inhibits the proliferation of bacteria by increasing phagocytic activity [7]

The National Center for Complementary and Alternative Medicine in the United States of America states that Echinacea has been shown as an effective way to treat and reduce the severity of respiratory infections [8]

In Egypt, Echinacea is a component of some drugs like; Immulant $175 \mathrm{mg}$ capsules, and Immulone lozenge (Echinacea $150 \mathrm{mg}+$ vitamin C 50mg). It is believed to activate monocytes macrophage cell function, increase leukocyte mobilization towards site of infection, and rise lysosomal enzyme activity of macrophages [9]

The aim of this study is to establish the effect of implementation of ventilator care bundle combined with Echinacea on length of stay in ICU, and mortality in mechanically ventilated patients.

\section{Patients and Methods}

A randomized controlled study was conducted in Surgical Intensive Care Unit (SICU) in Kasr Aini Hospital, where patients were admitted from general surgery and trauma units to receive mechanical ventilation.

The study included 80 patients, presented to SICU during the period between December 2013 and December 2014 constituted the study population. All patients were adults, more than 18 years old and intubated within 48 hours of admission to ICU. Patients who are drug induced immune compromised, had pneumonia, had witnessed aspiration, had hypersensitivity to Echinacea, or pregnant females are excluded.

All patients had ventilator care bundle applied and patients were divided into two groups: Group A; had Echinacea in the form of (Immulant capsules 350mg three times daily for 5 days), and Group $\mathrm{B}$; didn't receive Echinacea.

Ventilator care bundle consisted of 6 components: Head of bed elevation greater than 30 degree, daily sedation break by attempting daily dose reduction of continuous sedatives and by adjusting sedation to target ventilator adjusted motor assessment scoring scale, daily assessment for readiness for weaning, peptic ulcer prophylaxis by proton pump inhibitors (controloc 40mg) once daily or H2 antagonists, deep venous thrombosis prophylaxis by low molecular weight heparin unless contraindicated $(0.5 \mathrm{mg}$ per $\mathrm{Kg}$ once daily and dose is adjusted in renal patients), and topical buccal $1 \%$ chlorhexadine gel twice daily.

Compliance to ventilator care bundle was assessed daily by an independent observer. Compliance was recorded as yes or no for each bundle item. The entire bundle was considered compliant only if all 6 items were compliant. A bundle was considered noncompliant if any item was not performed, unless it is contraindicated.

\section{All patients were subjected to the following:}

Full history taking with special emphasis was made on cause of SICU admission, medications received, history of prior admission(s) to health care facility or ICU, and previous chest infection, and ongoing medications. Risk factors predisposing to chest infection were also particularly considered including; smoking, COPD, DM, old age, invasive chest trauma, immunocompromized patients, and major surgical interventions.

Through clinical examination with special emphasis on; chest condition and signs of pneumonia and COPD, signs of debility, hemodynamic status of the patient, body temperature, signs of complications of mechanical ventilation, and readiness for extubation. 
Laboratory investigations with special emphasis on admission and follow-up WBCs level, and sputum or trans bronchial aspirate culture and sensitivity if available.

Imagings with special emphasis on plain chest $\mathrm{X}$-ray on admission and as required.

Cases of VAP were identified by the attending intensivists during routine daily round using Clinical Pulmonary Infection Score (CPIS) [10]. A score of more than 6 is considered suggestive of pneumonia. Length of ICU admission, mortality and VAP associated mortality were compared between the two groups. The results were tabulated and statistically analyzed.

Table (1): Shows CPIS criteria and scoring.

\begin{tabular}{|c|c|c|}
\hline Item & Criteria & Score \\
\hline - Temperature & $\begin{array}{l}\cdot \geq 36.5 \text { and } \leq 38.4 \\
\bullet \geq 38.5 \text { and } \leq 38.9 \\
\bullet \geq 39 \text { and } \leq 36\end{array}$ & $\begin{array}{l}0 \\
1 \\
2\end{array}$ \\
\hline $\begin{array}{l}\cdot \text { Blood leucocytes, } \\
\mathrm{mm}^{3}\end{array}$ & $\begin{array}{l}\cdot \geq 4.000 \text { and } \leq 11.000 \\
\cdot<4.000 \text { or }>11.000 \\
\cdot<4.000 \text { or }>11.000 \\
\cdot+\text { band forms } \geq 50 \%\end{array}$ & $\begin{array}{l}0 \\
1 \\
2\end{array}$ \\
\hline - Tracheal secretions & $\begin{array}{l}\text { - Absence of tracheal secretions } \\
\text { - Presence of non purulent } \\
\text { secretions } \\
\text { - Presence of purulent secretions }\end{array}$ & $\begin{array}{l}0 \\
1 \\
2\end{array}$ \\
\hline $\begin{array}{l}\text { - Oxygenation }\left(\mathrm{PaO}_{2} /\right. \\
\left.\mathrm{FiO}_{2}\right), \mathrm{mmHg}\end{array}$ & $\begin{array}{l}\cdot>240 \text { or ARDS } \\
\cdot \leq 240 \text { and no ARDS }\end{array}$ & $\begin{array}{l}0 \\
2\end{array}$ \\
\hline $\begin{array}{l}\text { - Pulmonary } \\
\text { radiology }\end{array}$ & $\begin{array}{l}\text { - No infiltrate } \\
\text { - Diffuse or Patchy infiltrate } \\
\text { - Localized infiltrate }\end{array}$ & $\begin{array}{l}0 \\
1 \\
2\end{array}$ \\
\hline $\begin{array}{l}\text { - Progression of } \\
\text { pulmonary infiltrate }\end{array}$ & $\begin{array}{l}\text { - No radiographic progression } \\
\text { Radiographic progression } \\
\text { (after CHF \& ARDS excluded) }\end{array}$ & $\begin{array}{l}0 \\
2\end{array}$ \\
\hline $\begin{array}{l}\text { - Culture of tracheal } \\
\text { aspirate }\end{array}$ & $\begin{array}{l}\text { - Negative } \\
\text { - Positive }\end{array}$ & $\begin{array}{l}0 \\
2\end{array}$ \\
\hline
\end{tabular}

ARDS is defined as $\mathrm{PaO}_{2} / \mathrm{FiO}_{2} \leq 200$, pulmonary artery wedge pressure $\leq 18 \mathrm{mmHg}$, and acute pulmonary infiltrate.

\section{Statistical analysis:}

All data were collected, tabulated, and statistically analyzed. The descriptive statistics in the form of mean and standard deviation for quantitative data and frequency for qualitative data. The analytical statistics included Paired sample $(t)$ test, Chi square test for qualitative data analysis, and $p$-value to denotes the level of significance. All statistical calculations were done using computer program SPSS (Statistical Package for Social Science [11]

\section{Results}

The purpose of this study was to examine the effect of adding Echinacea purpura as an immunestimulant to the Ventilator Care Bundle (VCB) measures on length of ICU admission, and mortality.

At the start of the study ninety-six patients were included, nine patients were excluded because of receiving corticosteroids, four patients were excluded because of witnessed aspiration, and three patients were excluded because they didn't complete 48 hours on the mechanical ventilator.

Eighty (80) patients (64 males and 16 females), with age ranged from 19 to 79 years (mean age 49), who were intubated and connected to Mechanical Ventilator (MV) within 48 hours of admission to the Intensive Care Unit (ICU) in Kasr Aini Hospital constituted the population of this study as shown in Graph (1).

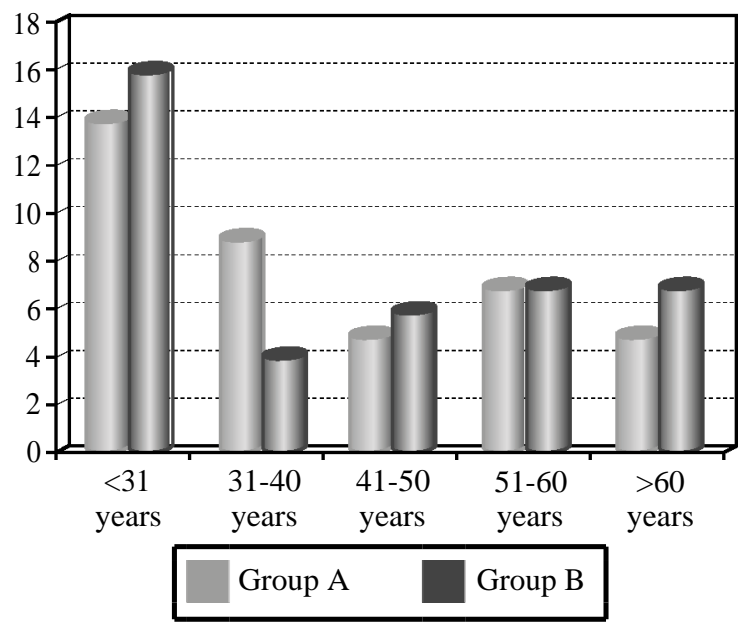

Graph (1): Age characteristics of study population.

Patients were divided into two (2) equal groups of forty (40) patients each; the first group (Group A) that included 40 patients (30 males and 10 females), had Immulant capsules (each capsule contains $175 \mathrm{mg}$ dry Echinacea extract) beside Ventilator Care Bundle (VCB) measures, and the second group (Group B) that included 40 patients (34 males and 6 females) had VCB measures only that were done in every patients of our included.

Duration of MV ranged from 2 to 31 days with a mean of $10 \pm 6$ in Group A, and from 4 to 35 day with a mean of $11 \pm 7$ in Group B. No statistical difference was found between both groups ( $p$-value $=0.238)$ as shown in (Table 2).

Length of stay in ICU (LOS) ranged from 4 to 34 day with a mean of $11 \pm 6$ day in Group A, and 
from 5 to 35 days with a mean of $13 \pm 7$ day in Group B. It was statistically not significant ( $p$ value of $=0.195$ ) as shown in (Table 2 ).

Table (2): Durations in both groups.

\begin{tabular}{lccc}
\hline & Group A & Group B & $p$-value \\
\hline Duration of MV & $10 \mathrm{~d}$ & $11 \mathrm{~d}$ & 0.238 \\
LOS & $11 \mathrm{~d}$ & $13 \mathrm{~d}$ & 0.195 \\
\hline
\end{tabular}

Prolonged intubation i.e. more than 7 days was found in 21 patients Group A and 26 patients in Group B with no statistical significance between both groups $(p$-value $=0.256)$ as shown in (Table 3$)$.

Mortality: Total mortality was $40(50 \%)$ patients; $21(26.2 \%)$ patients from Group A, and 18 $(22.5 \%)$ patients from Group B and that was statistically insignificant ( $p$-value $=0.655$ ) as shown in (Table 3) and Graph (2).

Table (3): Duration of intubation and mortality in both groups.

\begin{tabular}{lccc}
\hline & $\begin{array}{c}\text { Group A } \\
\text { Number of } \\
\text { patients } \\
\text { (percentage) }\end{array}$ & $\begin{array}{c}\text { Group B } \\
\text { Number of } \\
\text { patients } \\
\text { (percentage) }\end{array}$ & $p$-value \\
\hline $\begin{array}{l}\text { Patients with DOI } \\
>7 \text { days }\end{array}$ & $21(52.5 \%)$ & $26(65 \%)$ & 0.256 \\
- Mortality & $21(52.5 \%)$ & $18(45 \%)$ & 0.502 \\
\hline
\end{tabular}

*: Means significant.

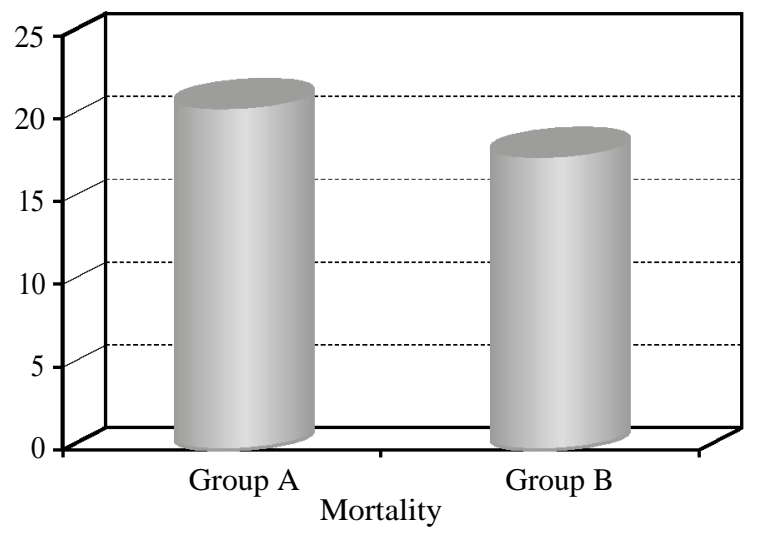

Graph (2): Mortality in both groups.

Total number of patients acquired VAP were $33(41.3 \%)$, fourteen patients in Group A, and ninteen patients in Group B ( $p$-value $=0.256)$ as shown in Graph (3) and (Table 4).

Total number of mortality between VAP patients was 18 (22.5\%), six patients in the Group A and twelve patients in Group B that was statistically significant ( $p$-value of $=0.04$ ) as shown in Graph (4) and Table (4).
Table (4): VAP characteristics in both groups.

\begin{tabular}{|c|c|c|c|}
\hline & Group A & Group B & D-value \\
\hline $\begin{array}{l}\text { - Patients with VAP (number } \\
\text { of patients (percentage) }\end{array}$ & $14(35 \%)$ & $19(47.5 \%)$ & 0.256 \\
\hline $\begin{array}{l}\text { - VAP associated mortality } \\
\text { (number of patients (per- } \\
\text { centage) }\end{array}$ & $6(15 \%)$ & $12(30 \%)$ & $0.04 *$ \\
\hline
\end{tabular}

*: Means significant.
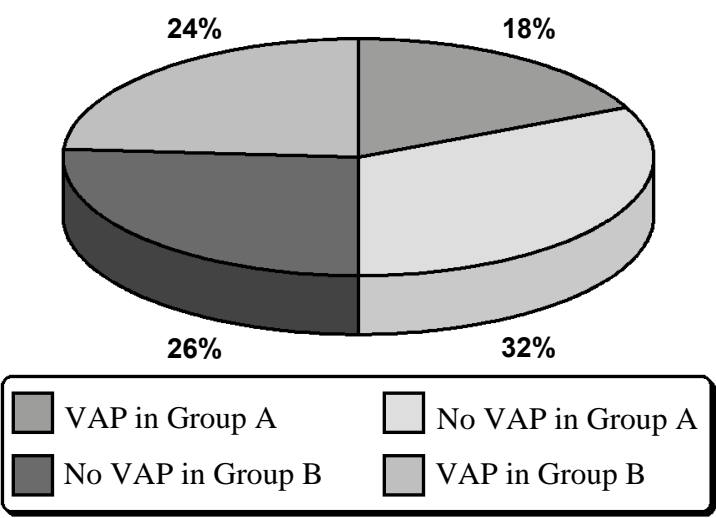

Graph (3): VAP incidence in both groups.

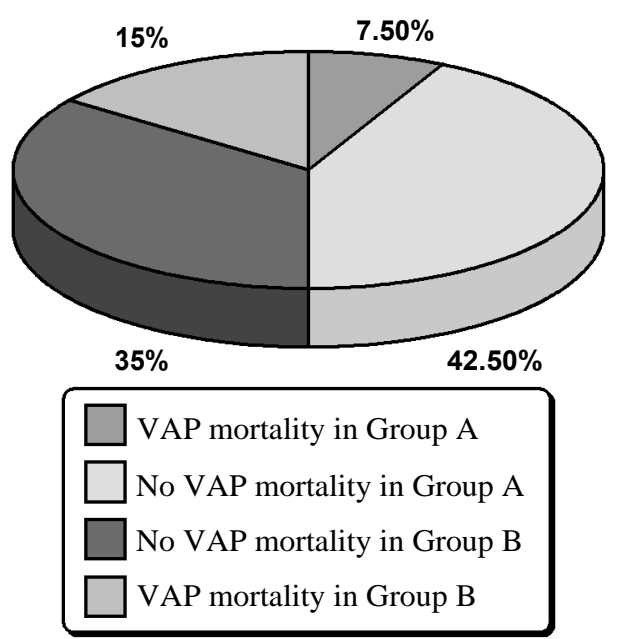

Graph (4): VAP associated mortality in both groups.

\section{Discussion}

Previous studies had demonstrated that, acquiring VAP in ventillated patients increases length of stay in ICU, and mortlity. The rate of contracting VAP has been described as $3 \%$ per day during the first week of mechanical ventilation, $2 \%$ per day in the ensuing weeks. The overall incidence of VAP ranges widely from $5 \%$ to $67 \%$ depending on the diagnostic criteria used [2]. Positive impact in reducing VAP on patient outcome including length of stay in ICU, and mortality through the implementation of Ventilator Care Bundle (VCB) that included the Center of Disease Prevention and Control (CDC) components [12]. Components of the bundle are used to prevent ventilator associated 
pneumonia, they may be ineffective against pneumonia when used separately but when grouped together, they decrease numbers of VAP in ICU [13].

In our study, we examined the effect of Echinacea (immulant capsules) on length of ICU admission and mortality when added to VCB.

Echinacea purpura is believed to be an immunestimulator, stimulating the body's non-specific immune system and warding off infections [14] that is used in prevention and treatment of Upper Respiratory Tract Infections (URTI). The European Medicines Agency (EMA) approved the use of expressed juice and dried expressed juice from fresh flowering aerial parts of Echinacea purpura for the short-term prevention and treatment of the common cold and upper respiratory tract infections [15]. A review from the University of Maryland on 13 European studies concluded that echinacea, when taken at first sign of cold, reduced cold symptoms or shortened their duration [15]

To our knowledge, this is the first research to study the role of Echinacea on reducing Lower Respiratory Tract Infections complications.

Despite the number of men is more than the number of women in the study, however, no significant difference regarding both mortality and prolonged stay between the genders was identified. Most of the studies confirmed these data [16]. On the contrary, Fowler et al., [17] found a higher mortality rate in women.

The fundamental results of our study were: The incidence of VAP was $41.25 \%$, (35\% in Group A, and $47.5 \%$ in Group B), with no significant changes between the two groups.

Bird et al., found that approximately 8 to 28 percent of critical care patients intubated during their stay in ICU will develop a VAP [20]. Some studies have reported a varied incidence from 17$30 \%$, depending upon the diagnostic criteria used in diagnosing VAP [22]. The reported incidence of VAP is higher in academic institutions [23]

Whether VAP is $100 \%$ preventable is controversial. Some hospitals have reported VAP rates at or close to 0 using prevention bundles [24]. Other experts have argued that VAP cannot be eliminated because they have had persistent VAP cases despite aggressive use of prevention bundles [25]. Blot et al argue that it is unrealistic to suggest that VAP can be eliminated in the most complex ventilated populations [26].
In our study duration of MV had a mean of 10 days ( $10 \pm 6$ days Group A, and $11 \pm 7$ days in Group B), with no significant difference between both groups $(p=0.238)$.

In a study by Mi Suk et al., throughout Virginia, North Carolina, South Carolina, and Georgia, the median duration of ventilation was 12 (4-21) days [27]. The adjusted mean duration of mechanical ventilation was (6.1 days; range, 3.0-11.2) for all ventilated patients in a recent study, published by Cambridge University Press on behalf of the Society for Healthcare Epidemiology of America, using the Institute for Health Metrics network (which includes community hospitals) [28]. Studies have shown that the risk of VAP increases with the increase in the duration of mechanical ventilation

In our study duration of ICU stay had a mean of 12 days ( $11 \pm 6$ day in Group A, and $13 \pm 7$ day in Group B). Mortality between patient population was $48.75 \%,(52.5 \%)$ patients in Group A, and (45\%) patients in Group B with no statistical significance between both groups.

Mortality among VAP patients was significantly lower in Group A $(n=6)$ than in Group B $(n=12)$ with a $p$-value of (0.04). VAP patient mortality in both groups was $(22.5 \%)$.

Bird et al., found that VAP patients carry a mortality rate of 15 to 25 percent [21]

Some analyses indicate that VAP is a severe disease, data on 200 patients led to the conclusion that nosocomial pneumonia is responsible for $60 \%$ of fatal infections in hospitals, being the leading cause of death due to hospital-acquired infections [30].The risk factors associated with a poor prognosis were age, mechanical ventilation duration and patients submitted to surgical interventions, especially non-elective surgeries [31]

Moreover, the longer the mechanical ventilation period, the longer the length of stay in the hospital and concurrently, the greater both the colonization rate and the incidence of resistant bacteria. There are reports of mortality rates of approximately $70 \%$ when resistant bacteria were involved in VAP [32] In studying the effects of Echinacea purpura dried extract on humoral immune response to Newcastle vaccination by Adel Feizil and Farhad Dadian [33], it showed that a significant reduction in mortality rate of treatment groups compared with the control group accounts for the herb's properties because the control of bacterial infections especially $E$. coli, have an important role in reducing mortality 
rate. This research showed that dried extract of E.purpurea can stimulate the immune system and increase the immune response of Newcastle vaccination [34]. These findings are compatible with Allen [32], Bodinet et al., [33] Frieier et al. [34] and Maas et al. [35] study results.

Based on the results obtained from the previous study, it was suggested that; the extract causes a reduction in the complications and mortality rate of the disease. It also decreases stress that leads to increase immunity and disease reduction [33].

\section{Conclusion:}

No apparent difference is found on adding Echinacea to VCB on decreasing length of ICU stay on ventilated patients, but Echinacea may be found to decrease VAP associated mortality. More studies are required to support this hypothesis.

\section{Recommendation:}

Independent studies on the effect of Echinacea on length of ICU stay, morbidity and mortality with a larger group of population are required to confirm our results and to provide more scientific knowledge about this herb.

If confirmed in independent studies, our finding that Echinacea is a strong immunostimmulant may decrease morbidity and mortality, may have important clinical applications.

\section{Study limitations:}

Our results were obtained in selected surgical ICU patients; they may not apply to all ICU patients.

Bias in diagnosis of VAP in ICU still present as the clinical diagnosis of VAP is neither sensitive nor specific [36].

Limited sample size is a limitation factors that may have affected the present study, and hence could not deduce statistical significance of the findings.

\section{Declaration of patient consent:}

All appropriate patient consent forms were obtained, patients gave their consent for their clinical information to be reported and understand that their names and initials will not be published.

\section{Financial support and sponsorship:}

Nil.

\section{Conflict of interest:}

There are no conflicts of interest.

\section{References}

1- CHASTRE J. and FAGON J.Y.: Ventilator-associated pneumonia. Am. J. Respir. Crit. Care Med., 165: 867 903, 2002.

2- SAFDAR N., DEZFULIAN C., COLLARD H.R. and SAINT S.: Clinical and economic consequences of ventilator-associated pneumonia: A systematic review. Crit. Care Med., 33: 2184-93, 2005.

3- MELSEN W.G., ROVERS M.M. and BONTEN M.J.: Ventilator-associated pneumonia and mortality: A systematic review of observational studies. Crit. Care Med. Oct., 37 (10): 2709-18, 2009.

4- SHAKEEL AMANULLAH and ZAB MOSENIFAR: Ventilator-Associated Pneumonia Overview of Nosocomial Pneumonias, Updated: Sep. 13. http://emedicine.medscape. . com/article/304836-overview, 2013.

5- DONALD E. CRAVEN and KARIN I. HJALMARSON: VAT Versus VAP Therapy Models o CID:51 (Suppl 1) o S592010.

6- MAAS N., BAUER J., PAULICKS B.R., BOHMER B.M. and MAIR D.A.: Efficiency of Echinacea purpurea on performance and immune status in pigs. J. Anim. Physiol. Anim. Nutr., 89: 244, 2005.

7- MICHAEL TIERRA R.H.: Treating Staph Infections Including MRSA with Echinacea. East West School of Planetary Herbology. http://www.planetherbs.com/ therap ie s/treating-staph-infections-including-mrsa-withechinacea.html, 2012.

8- JONATHAN McLELLAND: Herbal Remedy for Bacterial Chest Infection, Jun. 14, 2011, Article reviewed by Christine Brncik Last updated on: Jun. 14, 2011.

9- Dr. HENEINWELY and Dr. USAMA THARWAT: Drug Index, Master on Therapeutic drugs, 2003.

10- J.PUGIN: Clinical signs and scores for the diagnosis of ventilator associated pneumonia. Minerva Anestesiol., 68 (4): 261-5, 2002.

11- SPSS Inc., Chicago, IL, USA) release 15 for Microsoft Windows. 2006.

12- MUSCEDERE J., et al.: Comprehensive evidence-based clinical practice guidelines for ventilator associated pneumonia: Prevention. J. Crit. Care, 23: 126-37, 2008.

13- SCOTT M. and KEENE S.: What is the role of the allied health professional in preventing ventilator acquired pneumonia? Int. J. Infec. Diseases, 7 (1), 2009.

14- PAUL BERGNER, Echinacea: Eclectic Research, Its effect on the normal individual; with special reference to changes produced in the blood picture, 07-31-94 6 (2): 4-5 medical herbalism, Journal for medical practiotionar, 2001.

15- PAUL BERGNER: "Healing Power of Echinacea and Goldenseal and Other Immune System Herbs" (The Healing Power), prima publishing Feb.www.books.google. com.eg/books. 1997.

16- New Study on Echinacea is Faulty, says Canadian-Based Company Medical News Today, August 15, 2005.

17- FOWLER R.A., SABUR N., LI P., JUURLINK D.N., PINTO R., HLADUNEWICH M.A., et al.: Sex-and age- 
based differences in the delivery and outcomes of critical care. CMAJ, 177 (12): 1513-9, 2007.

18- LEE, VANESSA WALKER, LUKE F. CHEN, DANIEL J. SEXTON, and DEVERICK J. ANDERSON: The Epidemiology of Ventilator-Associated Pneumonia in a Network of Community Hospitals: A Prospective Multicenter Study Infect Control Hosp. Epidemiol. Jul., 34 (7): 657 62, 2013.

19- SUNDAR K.M., NIELSEN D. and SPERRY P.: Comparison of ventilator-associated pneumonia (VAP) rates between different ICUs: Implications of a zero VAP rate. J. Crit. Care, 27: 26-32, 2012

20- TONG J., GEOK M., LING T.L., CHENG T., OTHMAN A.S., ABDUL A.N., SHUKOR A. and HAR L.C.: Malaysian Registry of Intensive Care. The 2012 Report. Available at: http://www.mric.org.my/Content/Document/ MRICPublications/mricreport_pdf [accessed 07/08/2014], 2012.

21- BIRD D., ZAMBUTO A., O'DONNEL C., SILVA J., KORN C., BURKE R., BURKE P. and AGARWAL S. Adherence to ventilator-associated pneumonia bundle and incidence of ventilator-associated pneumonia in the surgical Intensive Care Unit. Archives Surgery, 145 (5): 465-70, 2010.

22- IBRAHIM E.H., TRACY L., HILL C., FRASER V.J. and KOLLEF M.H.: The occurrence of ventilator-associated pneumonia in a community hospital: Risk factors and clinical outcomes. Chest Aug., 120 (2): 555-61 10.1378/ chest. 120.2.555, 2001.

23- AKÇA O., KOLTKA K., UZEL S., CAKAR N., PEMBECI K., SAYAN M.A., et al.: Risk factors for early-onset, ventilator-associated pneumonia in critical care patients: Selected multiresistant versus nonresistant bacteria. Anesthesiology Sep., 93 (3): 638-45, 2000.

24- SUNDAR K.M., NIELSEN D. and SPERRY P.: Comparison of ventilator-associated pneumonia (VAP) rates between different ICUs: Implications of a zero VAP rate. J. Crit. Care, 27: 26-32, 2012.

25- BOUADMA L., DESLANDES E., LOLOM I., et al.: Long-term impact of a multifaceted prevention program on ventilator-associated pneumonia in a medical intensive care unit. Clin. Infect. Dis., 51: 1115-22, 2010.

26- BLOT S., LISBOA T., ANGLES R. and RELLO J.: Prevention of VAP: Is zero rate possible? Clin. Chest Med., 32: 591-9, 2011.

27- MOHANTY, SIDHARTH SRABAN ROUTRAY, DE-
BASIS MISHRA and ABHILAS DAS: Ventilator Associated Pneumonia in a ICU of a Tertiary Care Hospital in India Debaprasad, International Journal of Contemporary Medical Research, Volume 3, Issue 4, 2016.

28- RAMAKRISHNA PAI JAKRIBETTU, REKHA BOLOOR and SUCHARITHA SURESH: Comparison of microbiological profile of pathogens isolated from early-onset and late-onset ventilator-associated pneumonia in a tertiary care center. Volume 19, Issue 1, Page: 14-9, 2016.

29- JOÃOMANOEL Da SILVA JÚNIOR, EDERLON REZENDE, THAÍS GUIMARÃES, EDVALDO V. Dos CAMPOS, LUIZ ANDRÉ MAGNO, LÍVIA CONSORTI, RENATA ANDRÉA PIETRO PEREIRA, MARIA De LOURDES NASCIMENTO and JOÃO SILVA De MENDONÇA: VAP risk in relation to duration of MV. Braz $\mathrm{J}$. Infect Dis., Vol. 11, No. 5 Salvador Oct. 2007.

30- GALLAGHER J.: Implementation of ventilator-associated pneumonia clinical guideline (Bundle). The Journal for Nurse Practitioners, 8: 377-82, 2012.

31- JOÃO MANOEL Da SILVA JÚNIOR; EDERLON REZENDE; THAÍS GUIMARÃES; EDVALDO V. Dos CAMPOS; LUIZ ANDRÉ MAGNO; LIIVIA CONSORTI; RENATA ANDRÉA PIETRO PEREIRA; MARIA De LOURDES NASCIMENTO and JOÃO SILVA De MENDONÇA: VAP risk in relation to duration of MV. Braz J. Infect Dis. Vol. 11 No. 5 Salvador Oct., 2007.

32- FAGON J.Y., CHASTRE J., HANCE A.J., et al.: Nosocomial pneumonia in ventilated patients: A cohort study evaluating attributable mortality and hospital stay. Am. J. Med., 94: 281-8, 1993.

33- ADEL FEIZI and FARHAD DADIAN: The effects of Echinacea purpurea dried extract on humoral immune response of broiler chicks to Newcastle vaccination, African Journal of Biotechnology Vol. 11 (94): pp. 160958, 2012.

34- FRIEIER D.O., WRIGHT K., KLEIN K., VOLL D., DABIRI K., COSULICH K. and GEORGE R.: Enhancement of the humoral immune response by Echinacea purpurea in female Swiss mice. Immunopharmacol. Immunotoxicol., 25: 551-60, 2003.

35- MAAS N., BAUER J., PAULICKS B.R., BOHMER B.M. and MAIR D.A.: Efficiency of Echinacea purpurea on performance and immune status in pigs. J. Anim. Physiol. Anim. Nutr., 89: 244, 2005.

36- KLOMPAS M.: Ventilator-associated events surveillance: A patient safety opportunity. Curr. Opin. Crit. Care, 19: 424-31, 2013. 


\section{دراسة تآثير إستخدام الآخناسيا على مرضى الرعاية الذين يعتمدون

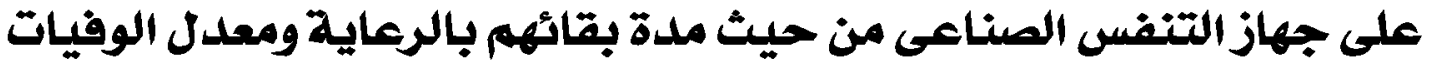

يعتبر إستخدام جهاز التنفس الصناعي بالرعاية المركزة من آكثر الآسباب المؤدية لإطالة مدة بقاء المريض بالرعائ الرائ المركزة وزيادة معدل

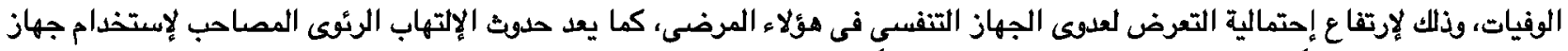

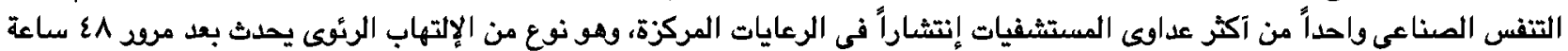

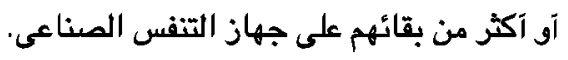

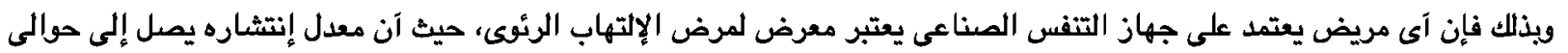

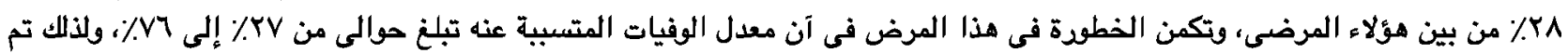

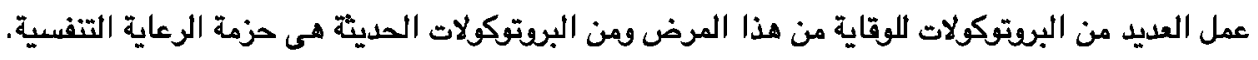

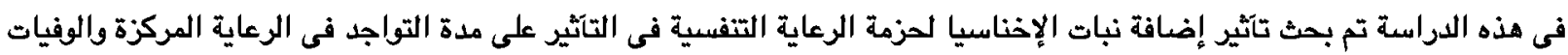

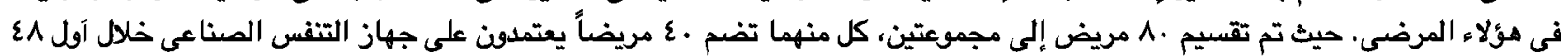

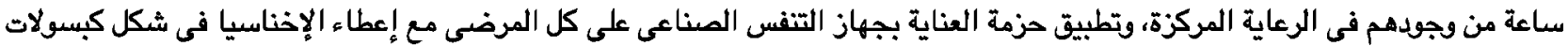

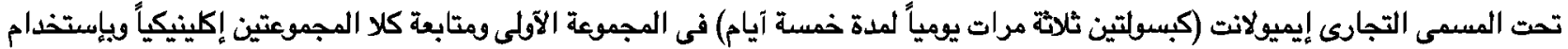
الآبحاث المناسبة.

وعند لدراسة النتائج وجدنا آنه لم يختلف عدد آيام التنفس المناعى وكذلك عدد آيام الوجود بالرعاية المركزة بين كلا المجموعتين بشكل مهم إحصائياً. لم يختلف آيضاً عدد الوفيات فى كلا المجموعتين بشكل مهم إحصائياً ولكن إختلف عدد الوفيات فى مرضى الإلتهاب الرئوى المصاحب لجهاز التنفس الصناعى فى كلا الهجموعتين بشكل مهم إحصائياً.

ومن النتائج السابقة فقد تم إفتراض آن الآخناسيا تساعد على التقليل من نسبة الوفيات المصاحبة للإلتهاب الرئوى فى مرضى الرعاية المركزة الذين يعتمدون على التنفس الصناعى. 